UDC 338.24:330.322

DOI: https://doi.org/10.32782/2413-9971/2020-29-32

\author{
Shaposhnykov Kostiantyn \\ Doctor in Economics, Professor, Head of the \\ Black Sea Research Institute of Economy and Innovation, Odesa
}

Шапошников К. С.

доктор економічних наук, професор, директор

Причорноморського науково-дослідного інституту

економіки та інновачій, м. Одеса

\title{
CORPORATE AND GENERAL STATE APPROACHES TO NATIONAL ECONOMY INVESTMENT ATTRACTIVE ENSURING
}

Summary. The theoretical corporate and state principles of ensuring the investment attractiveness of the national economy in the context of the implementation of the state investment policy are revealed in the article. It is noted that each country develops its own pragmatic sphere of realization of investment processes, formation of a set of factors that determine and provide for regulation of investment attractiveness, as well as tools that are oriented to achieve the highest efficiency from the use of the investment flows involved in the country's economy. It is substantiated that the formation of investment attractiveness within the framework of investment corporate and state policy instruments includes a wide range of measures and instruments that can be applied by the state to intensify the investment processes in the country. Among the main instruments of state regulation of the investment attractiveness of the national economy are the following: organizational, tax, instruments for intensifying investment activity, financial. Their specific features and nature of manifestation are revealed. The groups of corporate and state principles on which state regulation of investment attractiveness (fiscal, economic and social) are based and their key characteristics are defined. It is substantiated that ensuring the investment attractiveness of the national economy in the context of the implementation of the state model aims at increasing the inflow of internal and external investments by increasing the attractiveness of the country's business environment.

Key words: corporate governance, investment attractiveness, national economy, state regulation, state regulation of investment attractiveness, investment policy.

Introduction and problem statement. Ensuring the investment attractiveness of the national economy largely stems from the model of economic development of the country: the more developed the model of the economy, the more effectively its investment processes are organized. It should be noted that the choice of specific instruments for regulating these investment processes depends on the sectoral structure of the national economy, the level of development and condition of the institutional environment, the perfection of public and private institutions. Thus, in practice, it is not possible to form a single reference model of investment activity. Each country develops its own pragmatic sphere of implementation of investment processes, formation of a set of factors that determine and ensure regulation of investment attractiveness, as well as tools that are focused on achieving the highest efficiency from the use of the country's investment flows involved. Given that today's societies are formed from open economies, the level of development and their economic potential is quite diverse, with smaller and less developed economies being more difficult to overcome than the large ones, to overcome the barriers to entry into the world capital markets.

To address the internal problems of macroeconomic imbalances, the overwhelming majority of governments in these countries cooperate with international financial institutions, such as the IMF or the World Bank. At the same time, while noting such a level of cooperation, it does not directly contribute to the development of the economy in comparison with foreign direct investment flows, although it creates $[7 ; 8]$ a positive image of a solvent country for potential investors. That is why it is more important to create a favorable investment model in a country that does not contradict the principles of a market economy, the protection of private property, an appropriate level of trust in major institutions and, because emergent markets are risk-averse, flexible and privileged, in terms of national, guarantees for investors.
In this context, addressing the investment attractiveness of defining the role of the state in the implementation of the investment regulation model is an important theoretical and applied task of economic development during its structural adjustment and adaptation to external conditions and challenges.

Analysis of recent research and publications. The multifaceted and interdisciplinary nature of the problems of state regulation of investment processes, the formation and provision of investment attractiveness of the national economy are the subject of many scientific works. Scientists such as I. Blank, M. Borshch, P. Gaydutsky, M. were engaged in research of various aspects of the essential characteristics and features of the state investment policy, its structural components, peculiarities of regulation in this sphere, as well as the isolation of factors of influence on ensuring the investment attractiveness of the country. Denysenko, A. Duka, L. Zhalilo, T. Zatonatska, O. Litvin, T. Mayorov, A. Peresada, D. Pilevich, D. Stechenko, V. Fedorenko, and others. Despite the significant achievements of scientists, the dynamism and complexity of the investment environment causes the emergence of new factors affecting the investment attractiveness of the national economy, and therefore leads to the search and adaptation of new instruments to respond to changes in the implementation of the model of state regulation of investment activity in the country.

The purpose of this paper is to deepen theoretical approaches and development of proposals for the mechanism of formation of investment attractiveness of the national economy in the context of implementation of the model of state regulation of investment activity.

Research results. On the whole, state regulation is a system of instruments of various nature, which directly or indirectly affect the course of investment processes in the country and the economy. The influence of the state can occur during 
its direct participation in investment processes, although the state is the main source of formation of normative and organizational support for the efficiency of investment activity. In addition, government institutions are the guarantor of balanced and transparent investment processes in the economy, thereby ensuring self-confidence. The main task of state regulation is to provide favorable conditions for the activity of all economic entities (both internal and external), and not to limit the market mechanism and principles of market regulation. This will be, first of all, the introduction of a model of investment-market relations, which will strike a balance between domestic production and imports, on the other, the organization of the best and most efficient use of the corresponding capital flows.

Thus, repelling the state and structure of the economy, the level of development of its productive, financial, economic and scientific and technological capabilities, the state produces a particular model of investment activity. A. Tarabukina identifies such three models of investment policy as different approaches to investment objects [1]. The first model ("American") stimulates tax preferences, the second ("Japanese") is the direct involvement of the state in financing certain investment projects, the third model ("European") is the formation of the necessary infrastructure by the state, reducing the shortcomings in the interaction of market participants and encouragement. investment in human capital [1]. It should be emphasized that the application of established and tested models of investment policy in a transition economy is impractical because the transition market is non-linear and influenced by numerous endogenous and exogenous factors. In any model of investment policy, the state regulation of investment activity should be part of the general economic policy of the state. Instead, the application of specific regulatory instruments should depend on the level of market infrastructure development.

Government regulation of investment activity is also linked to realizing its competitive advantages. Traditionally, in economic theory, such factors distinguish the relative competitive advantage of each country as: location, land, natural resources, labor. However, these factors do not always affect the level of development of the country, and sometimes even play an indirect role. Thus, M. Porter, in determining the competitiveness of the country in the theory of competitive advantages, defined the state role of the variable that determines the directions of influence [2, p. 74-75].

Forming investment attractiveness within investment policy instruments involves a wide range of measures and instruments that can be applied by the state to intensify investment processes in the country. However, it should be borne in mind that the subjects of these processes are different in scope of activity, financial capacity, investment goals of legal and natural persons. This situation also causes difficulties in implementing an effective public investment policy, which would be oriented towards creating favorable business conditions for all these entities at the same time. The differences in the subjects 'future expectations should be taken into account, and therefore the subjects' approaches to assessing the investment attractiveness will differ. That is why it is expedient to consider the objective necessity of development and implementation in the country of "complementary investment policy of the state, which would by its essence effectively combine the expectations of all subjects regarding the country's investment climate, provide support for the formation of domestic investment resources and a harmonious combination of all sources of investment" [3].

A deeper understanding of the impact of the state's investment policy on the formation of investment attrac- tiveness is facilitated by an understanding of the principles of its provision.

By fiscal principles, through effective measures in the sphere of taxation, the state, on the one hand, creates its own investment resource and, on the other, creates a motivational field for rational management of taxes of economic entities in order to attract and use the investment. According to economic principles, other economic parameters are regulated (for example, income and expenses, profitability of the economy, conditions of the environment where transformational and transaction costs occur, etc.). Social principles characterize the impact of investment on the social, demographic and environmental situation in the country, as well as on the health of the population [4, p. 80-81].

It should be noted that adherence to these principles, aimed at increasing the inflow of investment capital through the creation of a favorable investment environment and its functional components, the formation of a positive investment image of the country, which will provide increased investment attractiveness of the national economy at such target points [4, p. 81].

In order to ensure the investment attractiveness of the national economy, it is considered appropriate to intensify the use of organizational, tax and financial instruments of state regulation.

The need to substantiate the priorities of state regulation in ensuring investment attractiveness is conditioned by the importance of reconciling national, regional and local economic interests of investors and the state in the investment process, the need for their institutional support, as well as increasing the level of trust in the country's basic institutions.

In general, the algorithm of providing investment attractiveness, based on theoretical and methodological principles of state regulation and involves the implementation of three main stages: a comprehensive evaluation the level of investment attractiveness of the national economy; systematization of direct and indirect methods and instruments of state regulation of the investment attractiveness of the national economy; direct determination of priorities of state regulation of investment attractiveness of national economy.

Conclusions. Ensuring the investment attractiveness of the national economy in the context of the implementation of the state and corporate model aims at increasing the inflow of internal and external investments by increasing the attractiveness of the country's business environment. Outlined in essence is the main objective of the state investment policy, and therefore the directions of its implementation in specific economic conditions are provided by the directions of realization of the stated goal of the investment policy, in particular, such as creating a favorable investment environment and its functional components, forming an optimal investment image of the country at the international level. In addition, securing investment attractiveness through the means and instruments of state regulation affect the socio-economic development of not only the whole country, but also of all other structural components.

It is advisable to consider state regulation of investment attractiveness as a separate direction of economic policy of the state, the purpose of which is to create favorable conditions for increasing the volume and increasing the efficiency of the use of investment resources, ensuring protection of the rights and interests of investors, controlling the origin and use of investments, directing them into important sectors of the economy. activities, socially significant projects and socioeconomic spatial development, formation of a positive investment image that ensures the investment attractiveness of the country and its territories. 


\section{References:}

1. Tarabukina O.M. (2008). Zakordonnyy dosvid derzhavnoho upravlinnya investytsiynoyu diyal'nistyu [Foreign experience of public investment management]. URL: http://www.rusnauka.com/11_EISN_2008/Economics/29053.doc.htm. (accessed 28 January 2020).

2. Porter M. (1990). The Competitive Advantage of Nations. The Free Press, A Division of Simon and Schuster Inc. - New York. 862 p.

3. Pilevych D.S. (2013). Sutnist' komplementarnoyi investytsiynoyi polityky derzhavy. [The essence of the complementary investment policy of the state]. Bulletin of Chernihiv State Technological University. No. 4 (70), pp. 127-132.

4. Lytvyn O.V. (2016). Sutnisni kharakterystyky ponyattya «derzhavna investytsiyna polityka» ta yoho element [Essential characteristics of the concept of "state investment policy" and its elements]. Market infrastructure. Issue 2, pp. 78-83.

5. Konakova K.M. (2018). Ekonomichni chynnyky ta priorytety derzhavnoho rehulyuvannya investytsiynoyi pryvablyvosti Ukrayiny [Economic factors and priorities of state regulation of investment attractiveness of Ukraine]. Scientific Bulletin of Kherson State University. Issue 30. Part 3. P. 36-39.

6. Stechenko D. M. (2002). Derzhavne rehuliuvannia ekonomiky: Navchalnyi posibnyk. [State regulation of Economy]. Kyiv: MAUP, $176 \mathrm{p}$.

7. Shaposhnykov K.S. Korporatyvni prava derzhavy: osoblyvosti realizatsii ta upravlinnia [State corporate rights: features of implementation and management]. Naukovi pratsi Kirovohradskoho natsionalnoho tekhnichnoho universytetu. Ekonomichni nauky. Vypusk 22. Tom 2. 2012. S. 57-62. URL: http://dspace.kntu.kr.ua/jspui/bitstream/123456789/933/1/12.pdf (accessed 20 January 2020).

8. Shaposhnykov K.S. Teleolohichni pidkhody do korporatyvnoho upravlinnia: tvorchist ta kreatyvnist [Teleological approaches to corporate governance: creativity and creativity]. Naukovi pratsi Kirovohradskoho natsionalnoho tekhnichnoho universytetu. Ekonomichni nauky. Vypusk 17. 2010. S. 67-70. URL: http://www.kntu.kr.ua〉doc/zb_17_ekon/stat_17/10.pdf. (accessed 28 January 2020).

\section{Список використаних джерел:}

1. Тарабукіна O.M. Закордонний досвід державного управління інвестиційною діяльністю. URL: http://www.rusnauka. com/11 EISN 2008/Economics/29053.doc.htm. (дата звернення: 28.01.2020).

2. Porter $\overline{\mathrm{M}}$. The $\bar{C}$ Competitive Advantage of Nations. The Free Press, A Division of Simon and Schuster Inc. - New York, $1990.862 \mathrm{p}$.

3. Пілевич Д.С. Сутність комплементарної інвестиційної політики держави. Вісник Чернігівського держсавного технологічного університету. № 4 (70), 2013. С. 127-132.

4. Литвин О.В. Сутнісні характеристики поняття «державна інвестиційна політика» та його елементи. Інфраструктура ринку. Випуск 2. 2016. С. 78-83.

5. Конакова К.М. Економічні чинники та пріоритети державного регулювання інвестиційної привабливості України. Науковий вісник Херсонського державного університету. Випуск 30. Частина 3. 2018. С. 36-39.

6. Стеченко Д.М. Державне регулювання економіки: Навчальний посібник. Київ : МАУП, 2002. 176 с.

7. Шапошников К.С. Корпоративні права держави: особливості реалізації та управління. Наукові праці Кіровоградського національного технічного університету. Економічні науки. Випуск 22. Том 2. 2012. C. 57-62. Режим доступу: http://dspace. kntu.kr.ua/jspui/bitstream/123456789/933/1/12.pdf_(дата звернення: 20.01.2020).

8. Шапошников К.С. Телеологічні підходи до корпоративного управління: творчість та креативність. Наукові праці Кіровоградського національного технічного університету. Економічні науки. Випуск 17. 2010. С. 67-70. Режим доступу: http://www.kntu.kr.ua〉doc/zb_17_ekon/stat_17/10.pdf. (дата звернення: 28.01.2020).

\section{КОРПОРАТИВНІ ТА ЗАГАЛЬНОДЕРЖАВНІ ПІДХОДИ ДО ЗАБЕЗПЕЧЕННЯ ІНВЕСТИЦІЙНОЇ ПРИВАБЛИВОСТІ НАЦІОНАЛЬНОЇ ЕКОНОМІКИ}

Анотація. У статті розкрито корпоративні та загальнодержавні підходи до забезпечення інвестиційної привабливості національної економіки. Серед основних інструментів державного та корпоративного регулювання інвестиційної привабливості національної економіки виділені такі: організаційні, податкові, інструменти щодо активізації інвестиційної діяльності, фінансові. Для розв'язання внутрішніх проблем, пов'язаних 3 макроекономічними дисбалансами, переважною більшістю уряди таких країн співпрацюють із міжнародними фінансовими організаціями, на кшталт МВФ чи Світового банку. Разом з тим, відзначаючи належний рівень такої співпраці, вона напряму не сприяє розвитку економіки, порівняно 3 потоками прямих іноземних інвестицій, хоча й створює позитивний імідж платоспроможної країни для потенційних інвесторів. Саме тому, важливіше створити сприятливу інвестиційну модель в країні, яка б не суперечила принципам ринкової економіки, захисту приватної власності, відповідного рівня довіри до основних інститутів i, оскільки емерджентні ринки схильні до ризиків, гнучкою системою пільг та розумних, 3 точки зору національних інтересів, гарантій для інвесторів. Необхідність обгрунтування пріоритетів державного регулювання в забезпеченні інвестиційної привабливості зумовлена важливістю узгодження національних, регіональних та локальних економічних інтересів інвесторів та держави у процесі інвестування, потребою їх інституційного забезпечення, а також підвищенням рівня довіри до базових інститутів країни. Розкриті їх специфічні особливості та характер прояву. Визначено групи принципів, на яких базується державне регулювання та корпоративні підходи до інвестиційної привабливості (фіскальні, економічні та соціальні) та наведені їх ключові характеристики. Запропоновано алгоритм забезпечення інвестиційної привабливості, що базується на теоретичних та методичних засадах державного регулювання і передбачає реалізацію трьох основних етапів: комплексне оцінювання рівня інвестиційної привабливості національної економіки; систематизація прямих та непрямих методів та інструментів державного регулювання інвестиційної привабливості національної економіки; безпосереднє визначення пріоритетів державного регулювання інвестиційної привабливості національної економіки. Обгрунтовано, що забезпечення інвестиційної привабливості національної економіки у контексті реалізації моделі державного та корпоративного підходів має на меті збільшення притоку внутрішніх та зовнішніх інвестицій за рахунок підвищення привабливості бізнес-середовища країни.

Ключові слова: інвестиційна привабливість, національна економіка, державне регулювання, державне регулювання інвестиційної привабливості, інвестиційна політика; корпоративне управління. 


\section{КОРПОРАТИВНЫЕ И ОБЩЕГОСУДАРСТВЕННЫЕ ПОДХОДЫ К ОБЕСПЕЧЕНИЮ ИНВЕСТИЦИОННОЙ ПРИВЛЕКАТЕЛЬНОСТИ НАЦИОНАЛЬНОЙ ЭКОНОМИКИ}

Аннотация. В статье раскрыты теоретические основы обеспечения инвестиционной привлекательности национальной экономики в контексте реализации государственной инвестиционной политики. Среди основных инструментов государственного регулирования инвестиционной привлекательности национальной экономики выделены следующие: организационные, налоговые, инструменты по активизации инвестиционной деятельности, финансовые. Раскрыты их специфические особенности и характер проявления. Определены группы принципов, на которых базируется государственном регулировании инвестиционной привлекательности (фискальные, экономические и социальные) и приведены их ключевые характеристики. Обосновано, что обеспечение инвестиционной привлекательности национальной экономики в контексте реализации модели государственного регулирования ориентировано на приток внутренних и внешних инвестиций за счет повышения привлекательности бизнес-среды страны.

Ключевые слова: инвестиционная привлекательность, национальная экономика, государственное регулирование, государственное регулирование инвестиционной привлекательности, инвестиционная политика, корпоративное управление. 